\title{
Who gets to look nice and who gets to play? Effects of child gender on household expenditures
}

\author{
Krzysztof Karbownik ${ }^{1} \cdot$ Michal Myck $^{2}$
}

Received: 2 March 2015/ Accepted: 24 February 2016/Published online: 3 March 2016

(C) The Author(s) 2016. This article is published with open access at Springerlink.com

\begin{abstract}
We examine the relationship between a child's gender and family expenditure using data from the Polish Household Budget Survey. Having a firstborn daughter as compared with a first-born son increases the level of household expenditures on child and adult female clothing, and it reduces spending on games, toys and hobbies. This could be a reflection of a pure gender bias on behalf of the parents or a reflection of gender complementarities between parents' and children's expenditures. We find no robust evidence on gender differences in educational investment, measured by kindergarten expenditure. The analysed expenditure patterns suggest a so-far unexamined role of gender in child development. Parents in Poland seem to pay more attention to how girls look and favour boys with respect to activities and play, which could have consequences in adult life and contribute to sustaining gender inequalities and stereotypes.
\end{abstract}

Keywords Gender differences - Household expenditures · Early childhood

JEL Classification $\quad \mathrm{D} 12 \cdot \mathrm{J} 13$

Michal Myck

mmyck@cenea.org.pl

Krzysztof Karbownik

krzysztof.karbownik@northwestern.edu

1 Institute for Policy Research, Northwestern University, 2040 Sheridan Road, Evanston,

IL 60208, USA

2 Centre for Economic Analysis - CenEA, ul. Królowej Korony Polskiej 25, 70-486 Szczecin, Poland 


\section{Introduction}

Children's gender has been demonstrated to influence family stability (Dahl and Moretti 2008), fertility (Ben-Porath and Welch 1976; Das 1987), abortion rates (Sen 1990; Jha et al. 2006), investment in nutrition and child care (Behrman 1988; Jayachandran and Kuziemko 2011; Barcellos et al. 2012), household expenditure (Lundberg and Rose 2004), educational and behavioural outcomes (Bertrand and Pan 2013, Autor et al. 2015), voting preferences (Oswald and Powdthavee 2010) and labour market activity (Lundberg and Rose 2002; Ichino et al. 2013). ${ }^{1}$ These effects are sometimes explained by gender-biased preferences of parents who, for example, would rather have a boy than a girl. On a number of outcomes, however, they are also consistent with gender-neutral preferences. In these instances, they refer to differences in costs of bringing up boys and girls, differences in the returns from investment in the child's human capital (especially prevalent in the developing world) and the importance of gender-specific roles in the upbringing process. In some cases, such as the effect on voting behaviour, the most natural explanation is a direct causal consequence of children's gender on changes in parental preferences. ${ }^{2}$

Using a detailed dataset on expenditures of Polish households, we extend the existing pool of evidence on the effects of children's gender to include its role in changing household consumption behaviour. Focusing on expenditure patterns may provide further clues in understanding the mechanisms behind the already-identified effects on parental outcomes. If there is differential treatment of boys and girls by their parents, then it should be reflected in the way households allocate their resources, which is of particular importance in the light of the growing evidence on the role of early interventions (Blau and Currie 2006; Cascio 2009; Almond and Currie 2011; Carneiro and Ginja 2014) and investment in children in the form of prenatal care, vaccinations or medical care (Aizer 2003; Figlio et al. 2009; Levine and Schanzenbach 2009). Thus, differential levels of expenditure related to the child's human capital development or on items that may solidify gender stereotypes could have long-term consequences for children's outcomes in the future.

The Polish Household Budget Survey (PHBS), which we use in this paper, offers a unique chance to study detailed patterns of household expenditures differentiated by a child's gender as well as other family characteristics. In contrast to most expenditure datasets, in the PHBS it is possible to classify a number of detailed expenditures by age and gender. This allows us to split spending between adults and children aged up to 12 and by gender among adults. ${ }^{3}$

\footnotetext{
${ }^{1}$ For a review of economic, sociological and psychological studies, see Raley and Bianchi (2006).

2 In Oswald and Powdthavee (2010), since children's gender enters their father's utility function, the outcome - in this case, parental voting behavior - is conditional on the number of boys and girls.

3 In the United States, the Consumer Expenditure Survey (CEX) also contains some information on child-specific expenditure such as clothing and private education. In the US data, however, children's goods are classified up to the age of 17 . This might be a problem because the older the children the more they take an active part in consumption decisions. Therefore, in the US, we often cannot distinguish between the decision of a teenager and that of a parent. Furthermore, CEX offers small sample sizes relative to the US population. For example, Blundell et al. (2008) start off with 192,564 households for years 1980 to 2004 but end up using only 14,430 households with complete data for their food demand estimation; Charles et al. (2009) use 1986 to 2002 data for all households and work with a sample of
} 
Using data for the years 2003-2011, in the main analysis we compare 14,893 married couples with first-born girls and 16,164 married couples with first-born boys to study the differential patterns of household expenditure. ${ }^{4}$ Subsequently we restrict the sample to families with two children of the same gender where we compare households with two girls versus two boys. ${ }^{5}$ Since we observe some families in two consecutive years, in total we work with the main sample of 46,185 observations and the two girls versus two boys sample of 9515 observations. We first discuss three main potential confounding factors, namely marital stability, fertility and labour supply. We then examine the effect of child's gender on total expenditure, adult clothing expenditure (Lundberg and Rose 2004) and child-related expenditure items, such as spending on clothing for children aged below 13 and expenditure on kindergarten. Additionally, we examine two categories of expenditure that include mainly child-related goods, namely 'games, toys and hobbies' and 'educational books and materials'.

We confirm that having a first-born girl decreases marital stability and fertility, but we do not find any relationship between child's gender and parental labour supply. Our findings suggest that the gender of children can have a significant effect on household expenditure patterns. We find that having a first-born girl increases spending on clothing and shoes by $3.6 \%$, and this overall effect is found to reflect a $7.2 \%$ increase in spending on women's clothing, a $5.8 \%$ decrease on men's clothing and a $6.0 \%$ increase on children's clothing (in all cases in the text when we refer to clothing, the category also includes shoes expenditure). Moreover, households with a first-born girl spend less on games, toys and hobbies (by $13.4 \%)$. We show that expenditure data can also be used to examine differential investment in human capital of sons and daughters. For example we find some suggestive yet not definitive evidence that spending on kindergarten in Poland is lower for girls. Overall the findings seem to point towards a gender-stereotypical pattern of child-related expenditure rather than deliberate differential investment in childhood human capital, with girls' parents buying them more clothing and boys'

\section{Footnote 3 continued}

49,363 households. Lundberg and Rose (2004) use a sample of approximately 2400 families for years 1990 to 1998 . Another problem in the case of the US is the much more lenient abortion legislation and evidence that immigrants from Asia keep their skewed gender preferences towards boys even long after immigration to North America (Almond et al. 2013). From this perspective, Poland offers a higher-quality and larger dataset, homogeneous population, strict abortion legislation and only limited access to in vitro fertilization (IVF) treatment. It is thus unlikely that our estimates will be biased due to lack of randomness in the gender of a child.

4 The descriptive statistics presented in Tables 1 and 2 document that the sample of married couples does not differ substantially from the population of all families. We further explain reasons for the sample selection in Sect. 4. We have also examined the relationship for the full population and for non-married individuals (mostly single mothers). Our results are unchanged qualitatively in the sample of all households and are often larger but statistically insignificant due to smaller sample sizes for non-married households. These additional analyses are available in Karbownik and Myck (2015).

5 If the gender of the first child affects family arrangements and fertility then focusing on the sample of households with two children can lead to sample selection bias. We discuss this possibility in Sect. 4. In the married sample with two children we observe 3002, families with two girls, 3539 families with two boys and 6554 mix-gender families. We do not use the mixed gender families in the estimation but the results are robust to including this set of households. 
Table 1 Descriptive statistics-demographics and labour market information

\begin{tabular}{|c|c|c|c|c|}
\hline & \multicolumn{2}{|c|}{ All families } & \multicolumn{2}{|c|}{ Married couples } \\
\hline & Mean & Girl-boy difference & Mean & Girl-boy difference \\
\hline Living without a father & $\begin{array}{l}0.090 \\
(0.286)\end{array}$ & $\begin{array}{l}0.004 \\
(0.002)\end{array}$ & - & - \\
\hline Having never been married & $\begin{array}{l}0.046 \\
(0.210)\end{array}$ & $\begin{array}{l}0.004 \\
(0.002)\end{array}$ & - & - \\
\hline Separated or divorced & $\begin{array}{l}0.044 \\
(0.205)\end{array}$ & $\begin{array}{l}0.001 \\
(0.002)\end{array}$ & - & - \\
\hline Married & $\begin{array}{l}0.867 \\
(0.340)\end{array}$ & $\begin{array}{l}-0.006 \\
(0.003)\end{array}$ & 1 & - \\
\hline Number of children & $\begin{array}{l}1.624 \\
(0.760)\end{array}$ & $\begin{array}{l}-0.005 \\
(0.007)\end{array}$ & $\begin{array}{l}1.664 \\
(0.765)\end{array}$ & $\begin{array}{l}-0.004 \\
(0.007)\end{array}$ \\
\hline First-born girl & $\begin{array}{l}0.481 \\
(0.500)\end{array}$ & - & $\begin{array}{l}0.480 \\
(0.500)\end{array}$ & - \\
\hline Age of mother & $\begin{array}{l}30.325 \\
(4.560)\end{array}$ & $\begin{array}{l}0.045 \\
(0.040)\end{array}$ & $\begin{array}{l}30.518 \\
(4.427)\end{array}$ & $\begin{array}{l}0.052 \\
(0.041)\end{array}$ \\
\hline Age of mother at first birth & $\begin{array}{l}24.199 \\
(3.874)\end{array}$ & $\begin{array}{l}0.010 \\
(0.034)\end{array}$ & $\begin{array}{l}24.333 \\
(3.800)\end{array}$ & $\begin{array}{l}0.014 \\
(0.035)\end{array}$ \\
\hline \multicolumn{5}{|l|}{ Mother's education $^{\mathrm{a}}$} \\
\hline Basic & $\begin{array}{l}0.342 \\
(0.474)\end{array}$ & $\begin{array}{l}-0.000 \\
(0.004)\end{array}$ & $\begin{array}{l}0.330 \\
(0.470)\end{array}$ & $\begin{array}{l}-0.003 \\
(0.004)\end{array}$ \\
\hline Secondary & $\begin{array}{l}0.359 \\
(0.480)\end{array}$ & $\begin{array}{l}-0.004 \\
(0.004)\end{array}$ & $\begin{array}{l}0.360 \\
(0.480)\end{array}$ & $\begin{array}{l}-0.006 \\
(0.004)\end{array}$ \\
\hline Higher & $\begin{array}{l}0.299 \\
(0.458)\end{array}$ & $\begin{array}{l}0.004 \\
(0.004)\end{array}$ & $\begin{array}{l}0.310 \\
(0.463)\end{array}$ & $\begin{array}{l}0.009 \\
(0.004)\end{array}$ \\
\hline Mother works & $\begin{array}{l}0.605 \\
(0.489)\end{array}$ & $\begin{array}{l}0.003 \\
(0.004)\end{array}$ & $\begin{array}{l}0.616 \\
(0.486)\end{array}$ & $\begin{array}{l}0.002 \\
(0.005)\end{array}$ \\
\hline Mother's income (PLN) & $\begin{array}{l}692 \\
(1020)\end{array}$ & $\begin{array}{l}-10 \\
(9)\end{array}$ & $\begin{array}{l}696 \\
(1021)\end{array}$ & $\begin{array}{l}-8 \\
(10)\end{array}$ \\
\hline Father works & - & - & $\begin{array}{l}0.93 \\
(0.25)\end{array}$ & $\begin{array}{l}0.000 \\
(0.002)\end{array}$ \\
\hline Father's income (PLN) & - & - & $\begin{array}{l}1673 \\
(1646)\end{array}$ & $\begin{array}{l}-6 \\
(15)\end{array}$ \\
\hline Observations & 53,300 & & 46,185 & \\
\hline Families & 35,917 & & 31,057 & \\
\hline
\end{tabular}

Notes The samples include families in which the mother is younger than 41 and older than 17 and had the first child at the earliest at the age of 16; children's age 0-12; expenditure information for households with at most one family with children aged 0-12. Monetary values in Polish zloty (PLN) in June 2006 prices. Columns one and three provide means and standard deviations while columns two and four provide differences between mean values for girls versus boys. Values in parentheses in even numbered columns correspond to $t$ test standard errors

Source Authors' calculations based on PHBS data, 2003-2011

a Education categories cover: basic_-no formal education, primary education, gymnasium and vocational education; secondary - secondary academic and secondary vocational education; higher educationeducation degree higher than secondary 
parents spending more on games. These findings naturally raise questions concerning long-term consequences of such behaviour for the development of boys and girls and their perception of social and gender roles.

The findings on clothing expenditure are consistent with a number of potential hypotheses, and are in line with those already documented in the US for the total clothing expenditure (Lundberg and Rose 2004). First of all, the gender of the first child might have a direct effect on parents' consumption preferences, which would be in line with the effect of having a girl on voting preferences (Oswald and Powdthavee 2010). Alternatively, mothers' and daughters' clothing might be complements, in which case spending more on one may lead to higher spending on the other, at the expense of fathers' clothing.

Our findings constitute first evidence suggestive of the fact that a child's gender affects the patterns of both parental and child-related expenditure. On the one hand, this evidence may reflect the direct effect of a child's gender on parental consumption preferences. On the other, it points towards a pattern of consumption suggestive of early assignment of stereotypical gender roles. Thus, girls get to look nice and boys get to play. Finally, we are also the first to study the relationship between children gender and household behaviour in a post-communist country.

\section{Data and sample statistics}

We use a dataset from the Polish Household Budget Survey for years 2003-2011. It is a nationally representative dataset collected annually by the Central Statistical Office in Poland (GUS). ${ }^{6}$ The data include information on household demographic composition and labour market activity, as well as income and expenditure data recorded over the period of a month in which households participate in the survey. In total, we have information on 323,754 households and 965,082 individuals over the 9 years from 2003 to 2011 . The PHBS contains a rolling panel element covering over a third of the participating households, which are interviewed in two consecutive years (in the same calendar month). In the full sample, we identify 121,382 households for which information is available for two periods.

Since the dataset does not contain retrospective fertility information, we rely only on contemporaneous family composition. Individuals in every household are matched into families, which we define as a single adult or a couple (married or cohabiting) with any dependent children. This is done using available information on the relationship to the head of household and detailed pairing in the data based on the unique identifiers of mothers, fathers and partners of each individual. Following other studies in the literature, we limit the analysis to mothers aged between 18 and 40 who had their first child at the earliest at the age of 16 . The limit for the age of the oldest child is set at 12 years, which is consistent with the approach of Dahl and

\footnotetext{
${ }^{6}$ For more information on the methodology used by GUS see Barlik and Siwiak (2011). The methodology complies with EUROSTAT recommendations. A summary of the survey methodology is given in the "Appendix".
} 
Table 2 Descriptive statistics-expenditure information

\begin{tabular}{|c|c|c|c|c|}
\hline & \multicolumn{2}{|c|}{ All families } & \multicolumn{2}{|c|}{ Married couples } \\
\hline & Mean & Girl-boy difference & Mean & Girl-boy difference \\
\hline \multicolumn{5}{|c|}{ Panel A: gender-specific adult expenditure (average amounts, PLN) } \\
\hline \multirow[t]{2}{*}{ Male } & 34.91 & -2.23 & 38.07 & -1.99 \\
\hline & $(108.02)$ & $(0.94)$ & $(112.73)$ & $(1.05)$ \\
\hline \multirow[t]{2}{*}{ Female } & 63.01 & 3.66 & 63.54 & 4.99 \\
\hline & $(137.68)$ & $(1.19)$ & $(128.49)$ & $(1.20)$ \\
\hline \multicolumn{5}{|c|}{ Panel B: Child-related expenditure (average amounts, PLN) } \\
\hline \multirow[t]{2}{*}{ Games and toys } & 21.22 & -3.33 & 22.22 & -3.04 \\
\hline & $(57.18)$ & $(0.5)$ & $(58.75)$ & $(0.55)$ \\
\hline \multirow[t]{2}{*}{ Educational materials } & 19.42 & 1.07 & 19.98 & 0.92 \\
\hline & $(63.23)$ & $(0.55)$ & $(63.87)$ & $(0.59)$ \\
\hline \multirow[t]{2}{*}{ Clothing and shoes } & 60.21 & 3.60 & 62.34 & 4.09 \\
\hline & $(90.46)$ & $(0.78)$ & $(92.29)$ & $(0.86)$ \\
\hline \multirow[t]{2}{*}{ Kindergarten } & 29.82 & -1.66 & 30.97 & -1.44 \\
\hline & $(94.16)$ & $(0.82)$ & $(96.35)$ & $(0.90)$ \\
\hline \multicolumn{5}{|c|}{ Panel C: child-related expenditure (\% with any positive expenditure) } \\
\hline \multirow[t]{2}{*}{ Games and toys } & 0.41 & -0.02 & 0.42 & -0.02 \\
\hline & $(0.49)$ & $(0.00)$ & $(0.49)$ & $(0.00)$ \\
\hline \multirow[t]{2}{*}{ Educational materials } & 0.34 & 0.02 & 0.35 & 0.02 \\
\hline & $(0.48)$ & $(0.00)$ & $(0.48)$ & $(0.00)$ \\
\hline \multirow[t]{2}{*}{ Clothing and shoes } & 0.67 & 0.01 & 0.69 & 0.02 \\
\hline & $(0.47)$ & $(0.00)$ & $(0.46)$ & $(0.00)$ \\
\hline \multirow[t]{2}{*}{ Kindergarten } & 0.15 & -0.00 & 0.15 & -0.00 \\
\hline & $(0.35)$ & $(0.00)$ & $(0.36)$ & $(0.00)$ \\
\hline \multirow[t]{2}{*}{ Total declared expenditure: } & 2557.35 & 12.14 & 2629.92 & 23.11 \\
\hline & $(1949.61)$ & $(16.9)$ & (1997.49) & $(18.60)$ \\
\hline Observations & 53,300 & & 46,185 & \\
\hline Families & 35,917 & & 31,057 & \\
\hline
\end{tabular}

Notes and source See Table 1

Moretti (2008) and at the same time corresponds to the grouping of expenditure information on clothing. ${ }^{7}$

Because expenditure data are collected at the household level, we additionally limit the sample to households where there is only one family with children below 13 years of age. This does not preclude the possibility of there being more than one family in the household (for example, parents living with children and their grandparents). In fact, such complex households are relatively common in Poland (Haan and Myck 2012). In the full PHBS sample, $71.0 \%$ of households contain

\footnotetext{
7 Sample selection bias is likely to be very small as schooling in Poland is compulsory until the age of 18 and most children live with their parents until at least that age.
} 
only one family, $22.2 \%$ include two and $6.8 \%$ three or more. In the main sample used in this analysis, $77.9 \%$ are single-family households. ${ }^{8}$ We further restrict the sample to families with a mother present in the household and where the childmother relationship is clearly specified in the data. We exclude twins and triplets at first birth, widowed mothers and lone fathers. ${ }^{9}$

The analysis is conducted, for the most part, for the sample of married couples. ${ }^{10}$ If the welfare of families is affected by the marital status of parents, and the latter driven to some extent by the gender of children, then any identified effect of gender on expenditure in the full sample could be a consequence of different partnership arrangements of girls' and boys' families, rather than directly a consequence of different expenditure behaviour of boys' and girls' parents. Section 4 also presents analysis of other potential sources of bias, namely the indirect effects of gender through fertility, parental labour supply or household income. Since we do not find a strong evidence for fertility effects we also present the main estimates for the sample of families with two children where both children are of the same gender. This sample provides a robustness test to verify the magnitude of the estimated effects. ${ }^{11}$ We chose the sample of married families for the main analysis based on two key premises: one, we can observe father's labour supply and expenditure on both male and female adult clothing; two, the outcomes that we observe in the married and the full sample are very similar. ${ }^{12}$

Descriptive statistics are presented in Table 1 separately for all families and for married couples. The sample size for all families is 53,300 and for the married couples, used in the main analysis, it is 46,185. Among all families, $9.0 \%$ of children live without a father. The fraction of families living without a father, in the full sample, can be decomposed into $4.6 \%$ of mothers who haven't been married and $4.4 \%$ of mothers who are divorced or separated. The average number of children in the full sample is 1.62 and it is lower than among married couples. As we show in Sect. 4 this could be due to the small first-born girl effects on having two or more children. At the same time, the demographic and socio-economic characteristics of the mothers are similar in the sample of all families and married

\footnotetext{
8 All our results hold regardless of whether we control for multifamily household status or not.

9 Lone fathers are defined as families in which mothers do not live with their children in the household. Paternal custody is rare in Poland. In the full sample we only have 492 cases of lone fathers aged 18-40 (which is the age group considered for estimation) of whom 60 are widowers. For comparison there are 9773 lone mothers in the full sample (827 widows) in the same age group.

${ }^{10}$ Results for the full sample of families and separately for non-married families have been presented in Karbownik and Myck (2015).

11 If the endogenous fertility is of a lesser concern then, similar to Lundberg and Rose (2004), we could also estimate the relationship between child's gender and expenditure for families with only one child. In this sample we know with much higher probability that particular child goods expenditure is directed towards specific child. Our results do not change substantively for this sample.

12 We recognize that focusing on married couples induces a potential selection bias but since the consumption results for all families and married couples are qualitatively unchanged and the quantitative differences are generally smaller in the latter sample we conclude that the bias is likely small and present the more conservative estimates for married copules. Detailed estimates for all samples are available in Karbownik and Myck (2015).
} 
families. These characteristics are also similar in the sample with two children of opposite gender.

The PHBS contains detailed information on over 400 specific household expenditure items collected over a period of a month. These items are aggregated into 11 basic broad categories of expenditures such as food, clothing, housing and energy, health, education and transport. Additionally, the dataset separates spending on such items as clothing and shoes into male and female adult (aged at least 13) and child (aged under 13) expenditures. ${ }^{13}$ Moreover, the detailed categories allow us to identify the following items (see Table 2):

- games, toys and hobbies (labelled as 'Games and toys');

- educational books and educational stationery ('Educational materials');

- kindergarten expenditure ('Kindergarten').

While the first two of these three categories could include spending on adult goods (e.g. on sports or fishing equipment and on training or educational books unrelated to children's education), they are most likely to cover child-related expenses. ${ }^{14}$ The last category is directly related to expenditure on children. ${ }^{15}$ Among all families and married families, $15 \%$ of households declare expenditure on kindergarten in the month of the survey; 67-69\% of families declare positive expenditure on child clothing, with an average (unconditional) expenditure of about 60 PLN (\$19) per month. ${ }^{16}$ Positive spending on games and toys is recorded in about $41 \%$ of the households, and about $34 \%$ declare positive expenditure on educational books and materials, with the average (unconditional) amounts spent on each of these categories equal to around 20 PLN (\$6) per month. Thus, married families do not seem to depart a lot from full population in terms of expenditure patterns. Columns two and four in Table 2 present our main "raw" results documenting differences in spending on children clothing, adult clothing as well as games and toys. The differences in spending on educational materials and kindergarten are more modest. As expected the average expenditure is generally

\footnotetext{
13 The total clothing category contains adult (male and female) and child clothing and shoes as well as several smaller items such as dyeing and cleaning.

14 The average expenditures in these categories in families without children are less than $25 \%$ of those among the families in our sample.

15 Our survey data also include information on schooling and tutoring expenditure. Given that primary schooling is for the most part public in Poland and we focus on households with the oldest child below the age of 13, the incidence of private schooling or tutoring is very low. About 10 and $1 \%$ of households declare any positive spending on schooling and tutoring, respectively. The nominal values are also very small. We could not detect any significant gender differences in expenditure on either of these categories. Furthermore, spending on kindergarten, as expected, is concentrated among children aged 3-6, for example among families with one child that declare positive kindergarten spending $91.9 \%$ of these children are between 3 and 6 years old, $5.7 \%$ are younger than three and $2.4 \%$ are older than six. We provide the estimates for the restricted sample of families with children who are age-eligible for kindergarten in Table 7 ("Appendix").

16 All absolute values are given in Polish zloty (PLN) in June 2006 prices. The exchange rate between the US dollar and the PLN on June 14, 2006 was \$1 = 3.194 PLN (National Bank of Poland). For reference: the gross monthly minimum and mean wages in Poland in 2006 were respectively 899.10 PLN (Ministry of Labour and Social Policy) and 2477.23 PLN (Central Statistical Office).
} 
higher once we focus on families with two children of the opposite sex. The gender differences are also aggravated, and we formally document this in a regression framework in Sect. 5.

\section{Modelling the effect of children's gender on household expenditures}

Our identification strategy relies on treating the child's gender at first birth as randomly determined. While some doubts have been raised with respect to the randomness of this outcome (Das Gupta 2005; Hesketh et al. 2005; Dahl and Moretti 2008; Almond and Rossin-Slater 2013), there are institutional reasons to believe that the random assignment is not confounded in the case of Poland. These include principally a culturally homogenous society, strict abortion legislation and very limited access to in vitro fertilization and other assisted reproductive treatments. ${ }^{17}$ The assumption of gender randomness implies that any differences that we observe in terms of household expenditure can be attributed to the gender of the child. Since the higher-parity fertility might be affected by the gender of the first child (see Table 4), the most common approach in the literature is to focus on the gender of the first child, in which case the estimated model for each of the expenditure categories takes the following form:

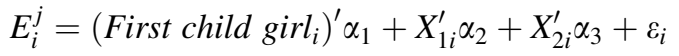

where $E_{i}^{j}$ is the expenditure of household $i$ in expenditure group $j$, vector $X_{1}$ contains mother's socio-demographic characteristics (mother's age at first birth, cubic polynomial in age, educational attainment indicators), while $X_{2}$ includes town size indicators and regional and year dummies. ${ }^{18}$ The First child girl indicator takes value 1 if the first-born child was a girl and 0 if it was a boy. $\varepsilon_{i}$ is the residual, which is clustered at household level because some households are observed twice in our data. Since we are interested in estimating the differences between a single female birth and a single male birth, we exclude twin and triplet births at first pregnancy from the sample. Equation (1) is estimated by ordinary least squares (OLS) in levels, and in each case we also report the percent effect. ${ }^{19}$ Since our consumption data are at the household level, especially in the case of endogenous subsequent fertility, the estimated differences based on the first-born child could be compressed among families with more than one child. Nonetheless, if the endogenous fertility

\footnotetext{
17 Poland has also very little immigration and in particular immigration from Asian countries where couples are known to exhibit strong gender preferences (Almond et al. 2013).

18 Maternal education and town size can be endogenous with respect to first child gender. First, when we do not control for these, the results remain unchanged. Second, we directly tested in a regression framework that a child's gender is not related to these controls. Expenditure estimates have also been produced controlling for fertility and they do not change qualitatively.

19 We could also compare twin-girl with twin-boy births, but we do not have enough power to credibly conduct such an analysis. Given that we observe some households multiple times, we have also estimated random effects models and models where we only keep the first or the second interview for each household. We present these results in Table 6 ("Appendix"). The conclusions remain qualitatively unchanged.
} 
effects are small we can also estimate the model using the sample of families with two or more children specifying if the first two children are either girls or boys. If the gender-stereotypical spending hypothesis is correct we would expect to see larger differences among households with two kids of the same gender than among all households with first-born girls versus boys.

As already noted above, our results should be interpreted with caution if there are substantial effects of child's gender on partnership stability, fertility or parents' labour supply. For example, if a first-born boy increases the probability of partnership stability, and this has a positive effect on family resources, then expenditure levels in such families could be higher. This would show up in the estimations as the effect of a first-born boy, but could reflect only the indirect effect of higher resources among families with a first-born boys, and not the effect of different expenditure patterns directly resulting from the gender of the first child. We show that partnership stability and fertility are significantly related to the gender of the first child in Poland, but parental labour supply is not. In most cases, however, the estimates for all and married families are very close, and in our results section we focus on the latter subsample in which we can analyse both maternal and paternal outcomes. Due to small sample sizes, we cannot provide meaningful inference in the case of unmarried mothers (Karbownik and Myck 2015).

\section{Potential confounding factors: partnership stability, fertility and labour supply}

In this section we first address the potential confounding factors in our analysis related to family structure, fertility and labour supply. This analysis also motivates our sample selection for consumption estimates. Table 3 presents regression results from the model specified in Eq. (1) for the probabilities of living without a father, of the mother having never been married and of the mother being divorced or separated conditional on having been married. A significant coefficient on the First child girl variable has usually been interpreted in the literature as a reflection of parents' gender preferences through its effect on the stability of parental partnership. Our results confirm the influence of the gender of the first-born child on family structure. The first child being a girl increases the probability of children living without a father by $5.8 \%$ and of the mother having never been married by $10.0 \%$. Unlike previous studies, however, we do not find any significant or sizable effects of first-born child gender on the probability of divorcing or separating conditional on being ever married. This could potentially be a consequence of the Polish legal system, in which it is much harder and more costly to obtain a divorce than in countries such as the US or Sweden. At the same time, in the sample with two boys and two girls we see large, but insignificant, estimates for the probability of divorce or separation. The results suggest that the gender of a child can have a detrimental effect on family stability through selection into marriage, and this could 
Table 3 Child's gender and family status

\begin{tabular}{lll}
\hline & All families & \multicolumn{1}{c}{$\begin{array}{l}\text { Two girls versus two } \\
\text { boys families }\end{array}$} \\
\hline Living without father & $0.005^{*}$ & 0.006 \\
\% effect & $(0.003)$ & $(0.005)$ \\
Observations & 5.8 & 13.9 \\
Mother having never been married & 53,300 & 10,274 \\
& $0.004^{* *}$ & 0.001 \\
\% effect & $(0.002)$ & $(0.003)$ \\
Observations & 10.0 & 4.2 \\
Mother separated or divorced & 53,300 & 10,274 \\
\% effect & 0.001 & 0.006 \\
Observations & $(0.002)$ & $(0.004)$ \\
\hline
\end{tabular}

Notes Standard errors clustered at household level $(* * * p<0.01$, ** $p<0.05, * p<0.1)$. Control variables include: mother's age at first birth, cubic polynomial in mother's age, mother's educational attainment indicators, town size indicators, regional and year dummies. Families with children living at home aged between 0 and 12; mothers aged below 41 and above 17; mother's age at first birth at least 16 years old. Column one presents estimates for all families while column two for families with first two born girls or first two born boys. The presented coefficients are for the indicator for first-born child being a girl or first two born children being girls

Source Authors' calculations based on PHBS data, 2003-2011

influence family resources and expenditure decisions. ${ }^{20}$ Therefore, especially in the case of families with two children, we focus on the sample of married couples.

Another important channel that can indirectly affect family expenditure is the influence of the gender of the first child on subsequent fertility, and hence its effects on total and per capita resources (Table 4 panel A). Furthermore, child's gender could influence not only fertility per se but also the spacing between the first and second child, and closely-spaced siblings might impose a larger financial burden on the household's budget. Fertility decisions could also be affected indirectly through the effect on partnership stability. For example, more stable relationships might result in higher fertility. Strong fertility effects would also preclude us from using the girl-girl versus boy-boy comparison.

Our results suggest that although a first-born's gender does not have an effect on total family size or spacing between the first and second births, a first-born girl does have a negative effect on fertility decisions at parity two. Married couples with firstborn daughters are around $2.4 \%$ less likely to have a second child than families

\footnotetext{
${ }^{20}$ Another way gender can affect family resources is through its effect on the probability of being raised in multi-family complex households. We do find some evidence for this in our data. Having a first-born girl increases the probability of living in a household with more than one family by $3.2 \%$ among all families, however, we do not find these effects for married couples. When we control for complex household structures in our expenditure regressions the results do not change so we conclude, akin to the fertility effects, that these are too small to substantively influence our main results.
} 
Table 4 Effect of child's gender on fertility, labour supply and income among married couples

\begin{tabular}{|c|c|c|c|}
\hline & All & $0-2$ & Two girls versus two boys families \\
\hline \multicolumn{4}{|l|}{ Panel A: family fertility } \\
\hline Total number of children & $\begin{array}{l}-0.007 \\
(0.008)\end{array}$ & - & - \\
\hline$\%$ effect & -0.4 & & \\
\hline Two or more children & $\begin{array}{l}-0.012 * * \\
(0.005)\end{array}$ & - & - \\
\hline$\%$ effect & -2.4 & & \\
\hline Time between first two births & $\begin{array}{l}-0.067 \\
(0.041)\end{array}$ & - & - \\
\hline$\%$ effect & -0.1 & & \\
\hline Observations & 46,185 & & \\
\hline \multicolumn{4}{|c|}{ Panel B: mothers'/households' labour supply } \\
\hline $\mathrm{P}($ working $)$ & $\begin{array}{l}-0.003 \\
(0.005)\end{array}$ & $\begin{array}{l}-0.004 \\
(0.010)\end{array}$ & $\begin{array}{l}0.007 \\
(0.011)\end{array}$ \\
\hline$\%$ effect & -0.4 & -0.8 & 1.1 \\
\hline Income from work & $\begin{array}{l}-15.060 \\
(9.626)\end{array}$ & $\begin{array}{l}-14.703 \\
(22.022)\end{array}$ & $\begin{array}{l}-13.540 \\
(21.699)\end{array}$ \\
\hline$\%$ effect & -2.1 & -2.3 & -2.0 \\
\hline Disposable income & $\begin{array}{l}-42.868 \\
(27.926)\end{array}$ & $\begin{array}{l}-36.784 \\
(51.404)\end{array}$ & $\begin{array}{l}-92.615 \\
(84.643)\end{array}$ \\
\hline$\%$ effect & -1.3 & -1.1 & -2.8 \\
\hline Observations & 46,185 & 9945 & 9515 \\
\hline \multicolumn{4}{|l|}{ Panel C: fathers' labour supply } \\
\hline $\mathrm{P}($ working $)$ & $\begin{array}{l}-0.000 \\
(0.003)\end{array}$ & $\begin{array}{l}0.003 \\
(0.005)\end{array}$ & $\begin{array}{l}0.000 \\
(0.006)\end{array}$ \\
\hline$\%$ effect & -0.1 & 0.3 & 0.0 \\
\hline Income from work & $\begin{array}{l}-8.483 \\
(16.054)\end{array}$ & $\begin{array}{l}-58.362 * \\
(30.900)\end{array}$ & $\begin{array}{l}30.996 \\
(36.059)\end{array}$ \\
\hline$\%$ effect & -0.5 & -3.3 & 1.8 \\
\hline Observations & 46,185 & 9945 & 9515 \\
\hline
\end{tabular}

Notes and source See Table 3. The "0-2" sample restricts the age of the oldest child to be lower or equal to two. Monetary values in Polish zloty (PLN) in June 2006 prices

with first-born sons. We do not find any statistically significant or economically meaningful evidence that gender affects fertility at any other parity margin and, given the fact that controlling for fertility does not alter our consumption estimates, we conclude that these relatively small effects should not substantially bias our main estimates. Because the fertility effect sizes are relatively small we present the consumption estimates also for families with first two girls versus first two boys, however, we treat these estimates with caution as gender of the child can be assumed, conditional on cultural and institutional caveats, to be purely random only in the case of the first birth. It is notable, though, that the negative coefficient on 
First child girl in the fertility equation points towards girl preferences, which seems to contradict our family stability findings. In this case, however, lower fertility could be driven by sample selection bias related to partnership stability.

Results in panels B and C show the effect of children's gender on parental employment, labour market income as well as on total household disposable income. The sample focuses on married mothers and their husbands but the results are very similar in the full population. ${ }^{21}$ The first column presents estimates for maximum number of families, the second column intends to uncover the direct effect of gender on outcomes that are independent from fertility by focusing on households where the oldest child is between 0 and 2 years old, while the third column displays estimates from the sample where we compare girl-girl to boy-boy families. ${ }^{22}$ In panel B we report results for mothers or households, and in panel C for labour supply of fathers. With the exception of a marginally significant effect on paternal labour income among families with oldest child between 0 and 2, we do not find any evidence that gender of the first-born child significantly affects any of the labour market outcomes. The estimates are generally small in magnitude compared with our consumption estimates and, if anything, they work in the opposite direction to the effects found for advanced economies in Ichino et al. (2013). Thus, in the case of Poland, we reject the hypothesis that the gender of a first-born child or first two children matters significantly for parental labour supply or household resources as proxied by disposable income.

\section{Differential expenditure by gender}

In this section, we present the main results (Table 5) from the model outlined in Sect. 3 for various expenditure categories: total household consumption, childrelated goods as well as clothing spending for adults split by gender. ${ }^{23}$

In the case of the total household expenditures we do not find any meaningful differences by either the gender of the first-born child or the first two children being of the same gender. At the same time there are gender differences in spending on clothing, and these are present for both children and adults. In particular, we can decompose the $3.6 \%$ increase in spending on clothing in families with first-born girls into a $5.8 \%$ reduction in adult male spending, a $7.2 \%$ increase in adult female

\footnotetext{
${ }^{21}$ Due to sample size limitations, we cannot credibly use widowhood as an exogenous shock to family resources. Nonetheless, when we estimate the labour supply regressions for the main sample of 294 widows, we cannot confirm any significant effects of child's gender on maternal labour supply. Furthermore, to increase power, we also use the whole sample and interact widowhood with first-born's gender. In this specification, we do not find any significant or sizable effects of either the gender dummy or the interaction term.

22 Arguably majority of mothers with children age 0-2 would not decide to have another child, and because of this we cannot estimate the comparison between two girls and two boys in this sample.

23 In the previous version of this paper (Karbownik and Myck 2015) we also presented the estimates for 11 broad expenditure categories e.g. food or services or durables. This is akin to the exercise in Lundberg and Rose (2004) and similarly to them, in majority of cases we did not observe any meaningful or statistically significant differences by gender of the first child. In the case of food and communication expenditures we detected statistically significant but not economically meaningful differences.
} 
spending and a $6.0 \%$ increase in child spending. These differentials are aggravated for the sample of families with two children of the same gender. ${ }^{24}$ This suggests that either there is a direct effect of child's gender on parental consumption preferences or there is a degree of complementarity between mothers' and daughters' clothing consumption that is also reflected in the reduction of spending on adult male clothing.

Among the analysed child-related expenditures other than clothing, we also find precisely estimated effects of the first-born's gender on other items of spending. On the intensive margin, these include 'games and toys' expenditure, which is lower among households with first-born girls by $13.4 \%$. On the extensive margin, households with first-born girls are less likely to declare expenditure within this category by $4.2 \%$. The differences for families with two children of the same gender are about twice the size in comparison to all families confirming our hypothesis of aggravated differentials in the sample with more extreme gender contrast. We also find that parents of first-born girls more frequently declare expenditure on 'educational materials'. At first, this seems contradictory to our results on games and toys; however, when we split this category into educational books and stationery, we find positive, substantive and significant coefficients only for the latter category. This suggests that families may have a lot of very small expenditures on educational stationery, such as pencils and crayons, which are skewed towards girls. This is further confirmed by moderate decrease in the estimated extensive margin effect between all families and families with either two girls or two boys, suggesting that some of these purchases could be transferable across children.

Finally, we find $5.1 \%$ reduction in kindergarten expenditures for households with first-born girls, which although marginally statistically insignificant ( $p$ value $0.105)$, is economically meaningful. These negative effects do not hold for the sample where we compare two girls to two boys. However, as we demonstrate in the "Appendix", this is because expenditure on kindergarten is strongly determined by the age of children as it can be positive only in households with children of eligible age. Table 7 in "Appendix" provides estimates taking into account presence of children in the relevant age range (3-6 years old), as well as their number and gender. ${ }^{25}$ Due to lack of statistical power our conclusions regarding kindergarten expenditure are not as strong as in the case of clothing or games and toys. The point estimates for households with one eligible girl (the dummy for a girl) are negative but insignificant in three out of four cases, and they seem to be driving the negative

\footnotetext{
${ }^{24}$ We chose families with exactly two children and both of the same gender for our analysis at parity two because this in our opinion provides the cleanest gender contrast. As a robustness check we also investigated the effects in three additional samples. First, sample of more than two children where we maintain the current treatment of two boys versus two girls. Second, sample with two children where we include mixed gender siblings. Third, sample of more than two children where we include all gender compositions and where the treatment is indicator for two girls. Our results do not change substantively in these samples, and as expected, in terms of magnitude they fall in between the comparison of first-born girl effects from the full sample and first two born girls effects from the sample of two girls and two boys.

${ }^{25}$ Detailed investigation of kindergarten expenditure suggests that among married families with two children of the same gender $71 \%$ declare positive spending if at least one of the children is aged three to six.
} 
Table 5 Child's gender and child expenditure among married couples

\begin{tabular}{|c|c|c|c|c|c|c|c|c|}
\hline & \multicolumn{4}{|c|}{$\begin{array}{l}\text { Married families with one or more } \\
\text { children }\end{array}$} & \multicolumn{4}{|c|}{$\begin{array}{l}\text { Married two children families: BB versus } \\
\text { GG families }\end{array}$} \\
\hline & $\begin{array}{l}\text { Intensive } \\
\text { margin }\end{array}$ & $\begin{array}{l}\% \\
\text { effect }\end{array}$ & $\begin{array}{l}\text { Extensive } \\
\text { margin }\end{array}$ & $\begin{array}{l}\% \\
\text { effect }\end{array}$ & $\begin{array}{l}\text { Intensive } \\
\text { margin }\end{array}$ & $\begin{array}{l}\% \\
\text { effect }\end{array}$ & $\begin{array}{l}\text { Extensive } \\
\text { margin }\end{array}$ & $\begin{array}{l}\% \\
\text { effect }\end{array}$ \\
\hline $\begin{array}{l}\text { Total } \\
\text { household } \\
\text { consumption }\end{array}$ & $\begin{array}{l}11.860 \\
(19.272)\end{array}$ & 0.5 & - & - & $\begin{array}{l}35.437 \\
(47.930)\end{array}$ & 1.3 & - & - \\
\hline $\begin{array}{l}\text { Games and } \\
\text { toys }\end{array}$ & $\begin{array}{l}-3.177 * * * \\
(0.593)\end{array}$ & -13.4 & $\begin{array}{l}-0.018 * * * \\
(0.005)\end{array}$ & -4.2 & $\begin{array}{l}-6.254^{* * *} \\
(1.361)\end{array}$ & -25.0 & $\begin{array}{l}-0.039 * * * \\
(0.011)\end{array}$ & -9.3 \\
\hline $\begin{array}{c}\text { Educational } \\
\text { materials }\end{array}$ & $\begin{array}{l}0.718 \\
(0.658)\end{array}$ & 3.7 & $\begin{array}{l}0.018 * * * \\
(0.004)\end{array}$ & 5.1 & $\begin{array}{l}1.710 \\
(1.572)\end{array}$ & 7.0 & $\begin{array}{l}0.017 * \\
(0.010)\end{array}$ & 3.9 \\
\hline $\begin{array}{l}\text { Children } \\
\text { clothing }\end{array}$ & $\begin{array}{l}3.610 * * * \\
(0.931)\end{array}$ & 6.0 & $\begin{array}{l}0.014 * * * \\
(0.005)\end{array}$ & 2.1 & $\begin{array}{l}10.592 * * * \\
(2.364)\end{array}$ & 15.8 & $\begin{array}{l}0.034 * * * \\
(0.010)\end{array}$ & 4.9 \\
\hline Kindergarten & $\begin{array}{l}-1.603 \\
(0.990)\end{array}$ & -5.1 & $\begin{array}{l}-0.005 \\
(0.004)\end{array}$ & -3.0 & $\begin{array}{l}1.693 \\
(2.657)\end{array}$ & 4.4 & $\begin{array}{l}-0.006 \\
(0.009)\end{array}$ & -3.4 \\
\hline $\begin{array}{l}\text { Adult male } \\
\text { clothing }\end{array}$ & $\begin{array}{l}-2.285^{* *} \\
(1.064)\end{array}$ & -5.8 & $\begin{array}{l}-0.017 * * * \\
(0.005)\end{array}$ & -4.0 & $\begin{array}{l}-2.008 \\
(2.417)\end{array}$ & -5.4 & $\begin{array}{l}-0.020 * \\
(0.011)\end{array}$ & -4.9 \\
\hline $\begin{array}{l}\text { Adult female } \\
\text { clothing }\end{array}$ & $\begin{array}{l}4.403 * * * \\
(1.286)\end{array}$ & 7.2 & $\begin{array}{l}0.018 * * * \\
(0.005)\end{array}$ & 3.0 & $\begin{array}{l}9.046 * * * \\
(3.116)\end{array}$ & 15.5 & $\begin{array}{l}0.037 * * * \\
(0.011)\end{array}$ & 6.4 \\
\hline Observations & 46,185 & & & & 9515 & & & \\
\hline
\end{tabular}

Notes and source See Table 3. BB is two boys and GG is two girls families. Monetary values in Polish zloty (PLN) in June 2006 prices

coefficient found in Table 5. In the case of two eligible children expenditure on kindergarten is more likely to be observed (the "both eligible" dummy) but the signs are inconsistent across the gender compositions.

We have also investigated whether the differentiated pattern of expenditure documented thus far is aggravated in families with lower socio-economic status based on maternal education. ${ }^{26}$ We do not find much support for this hypothesis with relatively similar spending on games and toys, however, the degree of complementarity between mother and first-born daughter spending on clothing (and substitutability with father's spending) is higher among more affluent families. This may be related to higher incomes and greater potential to treat clothing as luxury spending beyond the necessary expenditures in these families.

Results are also presented separately by subsamples defined by the age of the oldest child (Table 8 in "Appendix"), and older kids might express preferences towards particular items and influence households' expenditure patterns. We therefore split the data into families where the oldest child is either $0-4$ or $5-8$ or 9-12 years of age. The estimates of gender differentials seem to reflect a u-shape pattern in games and toys, clothing and educational materials, with the largest gender differentials in expenditure for children aged 5-8. These differences

26 These results are available in Karbownik and Myck (2015). 
however, in most cases, are not statistically significant due to relatively small sample sizes.

\section{Conclusion}

Gender of children has been shown to influence their parents' decisions in many important dimensions. There is also ample evidence from the developing countries that parents treat boys and girls differently when it comes to human capital investment. In both cases, the mechanisms believed to be responsible for parental decisions involve either biased preferences against one gender or an optimization mechanism reflecting different costs of investment in boys and girls or different returns from these investments. Some of the findings presented in this paper can also be explained within these frameworks. Parents may be biased against girls when it comes to expenditure on games, toys and hobbies (on average $13.4 \%$ ) and against boys when it comes to expenditure on children's clothing and shoes $(6.0 \%)$. They may also differentiate expenditure on boys and girls because they believe that there are different returns from such 'investments'. In our view, however, some of our results are difficult to square with these explanations and should rather be attributed to a direct effect of children's gender on parental preferences. For example, the fact that parents with first-born girls spend more on adult female and child clothing and less on adult male clothing than households with first-born boys is hard to reconcile with any of the above explanations using either gender-biased or gender-neutral preferences. $^{27}$

Differentiated spending on clothing and toys by child's gender, which could be thought of as gender stereotypical, could suggest a so-far unexamined role of gender in child development. The data suggest that while parents focus more on boys' activities, they pay more attention to how girls look, which is reflected in the expenditure on clothes. Expenditure data may also be informative on more direct forms of human capital investment such as spending on kindergarten. While the evidence in the PHBS in this regard is inconclusive we find some indication that parental investment decisions take gender of their kids into account, and although our estimates lack statistical power, they generally suggest that spending on girls is lower. If parents invest less in girls in this regard, this could potentially have important future consequences for the welfare of these children (Blau and Currie 2006). While we do not know what happens to these children later in adolescence and adulthood, the differentiated expenditure patterns we document could have consequences in adult life and contribute to sustaining gender inequalities.

Acknowledgments Data used in this paper come from the Polish Household Budget Survey (2003-2011) collected annually by the Polish Central Statistical Office (GUS). GUS takes no responsibility for the results and conclusions presented in this paper. We are grateful to Maja Adena, Per-Anders Edin, David Figlio, Rita Ginja, Jonathan Guryan, Hans Grönqvist, Mikael Lindahl, Björn Öckert and Erik Plug for valuable comments and suggestions, and to Judith Payne and Monika

\footnotetext{
27 As in Oswald and Powdthavee (2010), this would not have to imply a different utility function, but only conditionality of marginal utilities on the gender of children.
} 
Oczkowska for careful proofreading of the final manuscript. We are very grateful to two anonymous referees for comments on the early version of the paper. The article is part of a research project financed by the Polish National Science Centre (2012/05/B/HS4/01417), the support of which is gratefully acknowledged.

Open Access This article is distributed under the terms of the Creative Commons Attribution 4.0 International License (http://creativecommons.org/licenses/by/4.0/), which permits unrestricted use, distribution, and reproduction in any medium, provided you give appropriate credit to the original author(s) and the source, provide a link to the Creative Commons license, and indicate if changes were made.

\section{Appendix}

\section{Polish Household Budget Survey: summary of the methodology}

The Polish Household Budget Survey is a representative survey of Polish households. It is conducted every year and is spread over the entire calendar year, with each household surveyed over a period of a month during which it records its expenditures and incomes. This information is complemented with an additional interview, which is conducted at the end of each quarter of data collection (the socalled quarterly interview). Each year since 2005, when the most recent sampling procedure was introduced, the target sample is 37,584 households.

In the case of refusal to participate among households from the principal gross sample, households are replaced by another household from a reserve list of randomly-chosen households. This reserve list is prepared separately for each sampling unit. Households that drop out of the survey in the first half of their survey month are also replaced by households from the reserve list. Those that drop out in the second half of the month are not replaced. Households from the principal gross sample that agree to participate are re-interviewed in the same month of the following year. Households from the reserve list are not re-interviewed. The survey methodology has been developed in accordance with the EUROSTAT guidelines. The overall response rate in the survey in 2010 was $50.2 \%$. Survey non-response was due to refusal to participate $(48.1 \%)$, survey dropout during its duration $(1.6 \%)$ or refusal to complete the final quarterly interview $(0.1 \%)$. 
Table 6 First child's gender and child expenditure among married couples

\begin{tabular}{|c|c|c|c|c|c|c|}
\hline \multirow[t]{3}{*}{ Margin } & \multirow{2}{*}{\multicolumn{2}{|c|}{$\frac{\text { All families }}{\text { Random effects }}$}} & \multicolumn{4}{|c|}{ Families interviewed twice } \\
\hline & & & \multicolumn{2}{|c|}{ First interview } & \multicolumn{2}{|c|}{ Second interview } \\
\hline & Intensive & Extensive & Intensive & Extensive & Intensive & Extensive \\
\hline Games and toys & $\begin{array}{l}-3.239 * * * \\
(0.592)\end{array}$ & $\begin{array}{l}-0.018 * * * \\
(0.005)\end{array}$ & $\begin{array}{l}-2.934 * * * \\
(0.660)\end{array}$ & $\begin{array}{l}-0.018^{* * * *} \\
(0.006)\end{array}$ & $\begin{array}{l}-4.072 * * * \\
(0.709)\end{array}$ & $\begin{array}{l}-0.022 * * * \\
(0.006)\end{array}$ \\
\hline$\%$ effect & -13.7 & -4.3 & -12.7 & -4.3 & -16.0 & -5.1 \\
\hline Educational materials & $\begin{array}{l}0.778 \\
(0.656)\end{array}$ & $\begin{array}{l}0.016 * * * \\
(0.004)\end{array}$ & $\begin{array}{l}1.048 \\
(0.712)\end{array}$ & $\begin{array}{l}0.018 * * * \\
(0.005)\end{array}$ & $\begin{array}{l}0.807 \\
(0.751)\end{array}$ & $\begin{array}{l}0.014 * * * \\
(0.005)\end{array}$ \\
\hline$\%$ effect & 3.9 & 4.6 & 5.4 & 5.3 & 4.0 & 3.9 \\
\hline Clothing and shoes & $\begin{array}{l}3.767 * * * \\
(0.929)\end{array}$ & $\begin{array}{l}0.014 * * * \\
(0.005)\end{array}$ & $\begin{array}{l}4.488 * * * \\
(1.055)\end{array}$ & $\begin{array}{l}0.015 * * * \\
(0.005)\end{array}$ & $\begin{array}{l}3.769 * * * \\
(1.079)\end{array}$ & $\begin{array}{l}0.018 * * * \\
(0.005)\end{array}$ \\
\hline$\%$ effect & 6.2 & 2.1 & 7.5 & 2.2 & 6.1 & 2.7 \\
\hline Kindergarten & $\begin{array}{l}-1.385 \\
(0.973)\end{array}$ & $\begin{array}{l}-0.004 \\
(0.004)\end{array}$ & $\begin{array}{l}-1.009 \\
(1.067)\end{array}$ & $\begin{array}{l}-0.003 \\
(0.004)\end{array}$ & $\begin{array}{l}-1.447 \\
(1.143)\end{array}$ & $\begin{array}{l}-0.003 \\
(0.004)\end{array}$ \\
\hline$\%$ effect & -4.5 & -2.5 & -3.2 & -1.8 & -4.3 & -1.9 \\
\hline Observations & 46,185 & & 29,567 & & 28,548 & \\
\hline
\end{tabular}

Notes and source See Table 3. Monetary values in Polish zloty (PLN) in June 2006 prices. Robust standard errors in columns three to six

Table 7 Kindergarten expenditure: married couples

\begin{tabular}{|c|c|c|c|c|}
\hline & \multicolumn{2}{|c|}{$\begin{array}{l}\text { One or two children in the eligible age } \\
\text { range }\end{array}$} & \multicolumn{2}{|c|}{$\begin{array}{l}\text { One or two children in the eligible age } \\
\text { range and first eligible }\end{array}$} \\
\hline & Intensive margin & Extensive margin & Intensive margin & Extensive margin \\
\hline \multirow[t]{2}{*}{ Both eligible } & $40.839 * * *$ & $0.057 * * *$ & $35.584 * * *$ & 0.014 \\
\hline & $(7.313)$ & $(0.019)$ & (7.786) & $(0.021)$ \\
\hline \multirow[t]{2}{*}{ Girl-Boy } & -2.490 & $-0.022 * * *$ & -2.141 & -0.016 \\
\hline & $(2.439)$ & $(0.008)$ & $(3.644)$ & $(0.011)$ \\
\hline \multirow[t]{2}{*}{ Boy-Girl } & 0.206 & $-0.038 * * *$ & 0.039 & $-0.056 * * *$ \\
\hline & $(2.897)$ & $(0.009)$ & $(4.336)$ & $(0.012)$ \\
\hline \multirow[t]{2}{*}{ Girl-Girl } & 0.224 & 0.007 & -0.016 & 0.003 \\
\hline & $(8.677)$ & $(0.022)$ & $(8.876)$ & $(0.023)$ \\
\hline \multirow[t]{2}{*}{ Girl } & -0.430 & -0.031 & -0.689 & $-0.042 *$ \\
\hline & $(8.480)$ & $(0.023)$ & $(8.881)$ & $(0.024)$ \\
\hline Mean of $Y$ & 61.55 & 0.30 & 69.67 & 0.33 \\
\hline Observations & 21,205 & & 14,025 & \\
\hline Families & 15,213 & & 10,343 & \\
\hline
\end{tabular}

Notes and source See Table 3. Based on a sub-sample of households with one or two children who are age-eligible for kindergarten (3-6 years old). Reference group for families with one child are families where a boy is eligible, for those with two children-families with two boys who are age-eligible for kindergarten 
Table 8 First child's gender and child expenditure: married couples by age of the oldest child

\begin{tabular}{|c|c|c|c|c|c|c|c|}
\hline & \multicolumn{2}{|c|}{ Oldest child age $0-4$} & \multicolumn{2}{|c|}{ Oldest child age $5-8$} & \multicolumn{2}{|c|}{ Oldest child age $9-12$} & \multirow[t]{2}{*}{$p$ value } \\
\hline & Mean & Estimate & Mean & Estimate & Mean & Estimate & \\
\hline \multicolumn{8}{|c|}{ Panel A: intensive margin } \\
\hline Games and toys & 25.691 & $\begin{array}{l}-2.535^{* * * *} \\
(0.954)\end{array}$ & 24.434 & $\begin{array}{l}-3.934 * * * \\
(1.135)\end{array}$ & 16.218 & $\begin{array}{l}-3.014 * * * \\
(0.937)\end{array}$ & 0.629 \\
\hline Educational materials & 1.796 & $\begin{array}{l}0.307 \\
(0.219)\end{array}$ & 21.019 & $\begin{array}{l}1.074 \\
(1.039)\end{array}$ & 39.423 & $\begin{array}{l}0.614 \\
(1.695)\end{array}$ & 0.763 \\
\hline Clothing and shoes & 53.678 & $\begin{array}{l}2.295^{*} \\
(1.351)\end{array}$ & 63.944 & $\begin{array}{l}5.247 * * * \\
(1.637)\end{array}$ & 70.556 & $\begin{array}{l}3.390 * \\
(1.785)\end{array}$ & 0.373 \\
\hline \multicolumn{8}{|c|}{ Panel B: extensive margin } \\
\hline Games and toys & 0.499 & $\begin{array}{l}-0.017 * * \\
(0.008)\end{array}$ & 0.434 & $\begin{array}{l}-0.032 * * * \\
(0.009)\end{array}$ & 0.308 & $\begin{array}{l}-0.004 \\
(0.008)\end{array}$ & 0.058 \\
\hline Educational materials & 0.060 & $\begin{array}{l}0.008 * * \\
(0.004)\end{array}$ & 0.426 & $\begin{array}{l}0.024 * * * \\
(0.008)\end{array}$ & 0.616 & $\begin{array}{l}0.020 * * \\
(0.009)\end{array}$ & 0.118 \\
\hline Clothing and shoes & 0.677 & $\begin{array}{l}0.017 * * \\
(0.008)\end{array}$ & 0.698 & $\begin{array}{l}0.024 * * * \\
(0.008)\end{array}$ & 0.684 & $\begin{array}{l}0.001 \\
(0.008)\end{array}$ & 0.109 \\
\hline Observations & 16,909 & & 14,234 & & 15,042 & & 46,185 \\
\hline
\end{tabular}

Notes and source See Table 3. Last column displays $p$ values from the test that the three estimates for each expenditure category are equal

\section{References}

Aizer, A. (2003). Low take-up in Medicaid: Does outreach matter and for whom? American Economic Review Papers and Proceedings, 93(2), 238-241.

Almond, D., \& Currie, J. (2011). Human capital development before age five. Handbook of Labor Economics, 4, 1315-1486.

Almond, D., Edlund, L., \& Milligan, K. (2013). Son preference and the persistence of culture: Evidence from South and East Asian immigrants to Canada. Population and Development Review, 39(1), 75-95.

Almond, D., \& Rossin-Slater, M. (2013). Paternity acknowledgement in 2 million birth records from Michigan. PLoS ONE, 8(7), e70042.

Autor, D., Figlio, D., Karbownik, K., Roth, J., \& Wasserman, M. (2015). Family disadvantage and the gender gap in behavioral and educational outcomes. IPR Working paper 15-16.

Barcellos, S., Carvalho, L., \& Lleras-Muney, A. (2012). Child gender and parental investments in India: Are boys and girls treated differently? NBER Working Paper 17781.

Barlik, M., \& Siwiak, K. (2011). Metodologia badania budżetów gospodarstw domowych, Zeszyty Metodologiczne GUS. Warszawa: Zakład Wydawnictw Statystycznych.

Behrman, J. (1988). Intrahousehold allocation of nutrients in rural India: Are boys favored? Do parents exhibit inequality aversion? Oxford Economic Papers, 40(1), 32-54.

Ben-Porath, Y., \& Welch, F. (1976). Do sex preferences really matter? Quarterly Journal of Economics, 90(2), 285-307.

Bertrand, M., \& Pan, J. (2013). The trouble with boys: Social influences and the gender gap in disruptive behaviour. American Economic Journal: Applied Economics, 5(1), 32-64.

Blau, D., \& Currie, J. (2006). Pre-school, day care, and after-school care: Who's minding the kids? Handbook of the Economics of Education, 2, 1163-1278.

Blundell, R., Pistaferri, L., \& Preston, I. (2008). Consumption inequality and partial insurance. American Economic Review, 98(5), 1887-1921. 
Carneiro, P., \& Ginja, R. (2014). Long term impacts of compensatory preschool on health and behaviour: Evidence from Head Start. American Economic Journal: Economic Policy, 6(4), 135-173.

Cascio, E. (2009). Do investments in universal early education pay off? Long-term effects of introducing kindergartens into public schools. NBER Working Paper 14951.

Charles, K. K., Hurst, E., \& Roussanov, N. (2009). Conspicuous consumption and race. Quarterly Journal of Economics, 124(2), 425-467.

Dahl, G. B., \& Moretti, E. (2008). The demand for sons. Review of Economic Studies, 75(4), 1085-1120.

Das, N. (1987). Sex preferences and fertility behaviour: A study of recent Indian data. Demography, 24(4), 517-530.

Das Gupta, M. (2005). Explaining Asia's missing women: A new look at the data. Population and Development Review, 31(3), 529-535.

Figlio, D., Hamersma, S., \& Roth, J. (2009). Does prenatal WIC participation improve birth outcomes? New evidence from Florida. Journal of Public Economics, 93(1-2), 235-245.

Haan, P., \& Myck, M. (2012). Multi-family households in a labour supply model: a calibration method with application to Poland. Applied Economics, 44(22), 2907-2919.

Hesketh, T., Liu, L., \& Xing, Z. W. (2005). The effect of China's one-child family policy after 25 years. New England Journal of Medicine, 353(11), 1171-1176.

Ichino, A., Lindström, E.-A., \& Viviano, E. (2013). Hidden consequences of a first-born boy for mothers. Economics Letters, 123(3), 274-278.

Jayachandran, S., \& Kuziemko, I. (2011). Why do mothers breastfeed girls less than boys? Evidence and implications for child health in India. Quarterly Journal of Economics, 126(3), 1485-1538.

Jha, P., Kumar, R., Vasa, P., Dhingra, N., Thiruchelvam, D., \& Moineddin, R. (2006). Low male-tofemale sex ratio of children born in India: National survey of 1.1 million households. Lancet, 367(9506), 211-218.

Karbownik, K., \& Myck, M. (2015). Who gets to look nice and who gets to play? Effects of child gender on household expenditure. IPR WP 15-03.

Levine, P.B., \& Schanzenbach. D. (2009). The impact of children's public health insurance expansions on educational outcomes. NBER Working Paper 14671.

Lundberg, S., \& Rose, E. (2002). The effects of sons and daughters on men's labor supply and wages. Review of Economics and Statistics, 84(2), 251-268.

Lundberg, S., \& Rose, E. (2004). Investments in sons and daughters: Evidence from the consumer expenditure survey. In: A. Kalil \& T. DeLeire (Eds.), Family investments in children: Resources and parenting behaviors that promote success (pp. 163-180). Mahwah, NJ: Lawrence Erlbaum Associates.

Oswald, A. J., \& Powdthavee, N. (2010). Daughters and left-wing voting. Review of Economics and Statistics, 92(2), 213-227.

Raley, S., \& Bianchi, S. (2006). Sons, daughters, and family processes: Does gender of children matter? Annual Review of Sociology, 32, 401-421.

Sen, A. (1990). More than 100 million women are missing. New York Review of Books, 37(20), 61-66. 